\title{
Disposable Strip-Type Biosensors for Amperometric Determination of Galactose
}

Kihak Gwon, Seonhwa Lee, Hakhyun Nam, and Jae Ho Shin*

Department of Chemistry, Kwangwoon University, 20 Kwangwoon-ro, Nowon-gu, Seoul 01897, Republic of Korea

\begin{abstract}
A development of disposable strip-type galactose sensor for point-of-care testing (POCT) was studied, which was constructed using screen-printed carbon electrodes. Galactose levels were determined by the redox reaction of galactose oxidase in the presence of potassium ferricyanide as an electron transfer mediator in a small sample volume (i.e., less than $1 \mu \mathrm{L}$ ). The optimal performance of biosensor was systematically designated by varying applied potential, operating $\mathrm{pH}$, mediator concentration, and amount of enzyme on the electrode. The sensor system was identified as a highly active for the galactose measurement in terms of the sensitivity (slope $=4.76 \pm 0.05 \mathrm{nA} / \mu \mathrm{M}$ ) with high sensor-to-sensor reproducibility, the linearity $\left(\mathrm{R}^{2}=0.9915\right.$ in galactose concentration range from 0 to $\left.400 \mu \mathrm{M}\right)$, and response time $\left(t_{95 \%}=<17 \mathrm{~s}\right)$. A lower applied potential (i.e., $0.25 \mathrm{~V}$ vs. $\mathrm{Ag} / \mathrm{AgCl}$ ) allowed to minimize interference from readily oxidizable metabolites such as ascorbic acid, acetaminophen, uric acid, and acetoacetic acid. The proposed galactose sensor represents a promising system with advantage for use in POCT.
\end{abstract}

Keywords : Galactose Sensor, Disposable Strip-Type Electrode, Point-Of-Care Testing (POCT), Screen-Printed Carbon Electrodes (SPCEs)

Received : 15 July 2019, Accepted : 2 April 2020

\section{Introduction}

Quantitative determination and control of galactose levels in newborns is clinically important [1,2]. Increased levels of galactose $(>240 \mu \mathrm{M})$ in the blood and urine indicate galactosemia, which is a genetically inherited metabolic disorder characterized by an inability to utilize galactose and very little or a complete lack of enzymes that metabolize this sugar [3-5]. Intake of galactose sources such as milk and dairy products by infants with galactosemia leads to galactose accumulation in the body, unless quickly treated, which may lead to liver disease, cataracts, brain damage, and sometimes death [6-7]. Therefore, there is a need to develop sensitive and specific point-of-care tests (POCT) for the diagnosis of galactosemia that allows simple, accurate, and rapid determination of galactose levels [8].

*E-mail address: jhshin@ $@$ kw.ac.kr

DOI: https://doi.org/10.33961/jecst.2019.00437

This is an open-access article distributed under the terms of the Creative Commons Attribution Non-Commercial License (http://creativecommons.org/licenses/by-nc/4.0)
which permits unrestricted non-commercial use, distribution, and reproduction in any which permits unrestricted non-commercial use, distri
medium, provided the original work is properly cited.
The determination of galactose has been investigated through various methods, such as fluorometry [9-12], polarimetry [13], and chromatography $[13,14]$ but these methods have the disadvantages of time-consuming, expensive, and unsuitable for POCT. In contrast, the enzyme based electrochemical approach has great potential in POCT because of its high sensitivity, easy use, cost-effectiveness, fast test, rapid patient treatment, and promising automation [15-17].

Generally, two-types of enzymes can be used for electrochemical galactose measurements, galactose dehydrogenase (GDH) and galactose oxidase (GAO), which differ in their ability to react with external electron acceptors. GDH is unable to utilize oxygen as an electron acceptor and requires a non-protein electron acceptor such as nicotine adenine dinucleotide (NAD) or nicotine adenine dinucleotide phosphate (NADP) [18]. In contrast, GAO can utilize oxygen as an external electron acceptor to release hydrogen peroxide $\left(\mathrm{H}_{2} \mathrm{O}_{2}\right)[15,18]$. It is well known that GAO catalyzes the oxidation of galactose as shown below: 
D-galactose $+\mathrm{H}_{2} \mathrm{O}+\mathrm{O}_{2}+\mathrm{GAO} \rightarrow$ meso-galactohexodialdose $+\mathrm{H}_{2} \mathrm{O}_{2}$

At electrode: $\mathrm{H}_{2} \mathrm{O}_{2} \rightarrow 2 \mathrm{H}^{+}+\mathrm{O}_{2}+2 \mathrm{e}^{-}($at $0.7 \mathrm{~V}$ vs. $\mathrm{Ag} / \mathrm{AgCl})$

From the above reactions, it can be seen that the production of $\mathrm{H}_{2} \mathrm{O}_{2}$ can be easily monitored amperometrically. In other words, an electrochemical biosensing mechanism for galactose is based on the amperometric monitoring of the electroactive $\mathrm{H}_{2} \mathrm{O}_{2}$ generated by the enzyme-catalyzed reaction. However, this method has a large dependence on the amount of dissolved oxygen present in the sample, and a high oxidation potential $(0.7 \mathrm{~V}$ vs. $\mathrm{Ag} / \mathrm{AgCl})$ is applied when measuring the oxidation current of $\mathrm{H}_{2} \mathrm{O}_{2}[19,20]$. Thus, other metabolites including ascorbic acid, acetaminophen, uric acid, and acetoacetic acid can be oxidized with galactose at the electrode, causing a serious measurement error. To solve this problem, electron transfer mediators such as ferrocene and its derivatives [3,7,21-23], cobalt phthalocyanine [21,24], ruthenium [25], and ferricyanide [26], are used to lower the applied potential and reduce the effects of interfering metabolites.

Disposable electrochemical biosensors are mainly manufactured using the screen-printing method, as it is simple, cheap, and easy for mass production $[5,8,20,21,24,25]$. A survey of the literature indicates that only a few studies have investigated galactose measurement using planar-type screen-printed carbon electrodes [3,5,27]. However, varying sample volumes applied to planar-type sensors may affect the accuracy of the results. To improve accuracy, we developed a disposable galactose biosensor based on strip-type screen-printed carbon electrodes (SPCEs), which is similar to a commercially available blood glucose sensor [28]. To the best of our knowledge, there have been few reports for the galactose measurements using the SPCEs $[3,5,27]$.

In this study, we report a disposable strip-type biosensor fabricated by immobilizing a mixture of enzyme (GAO) and electron transfer mediator $\left(\mathrm{K}_{3} \mathrm{Fe}(\mathrm{CN})_{6}\right)$ on the screen-printed electrode for amperometric determination of galactose. This sensor system is sufficiently sensitive, selective, and rapid to determine galactose concentrations using small sample volumes $(<1 \mu \mathrm{L})$.

\section{Experimental}

Reagents. The reagents used were as follows: Galactose oxidase (EC 1.1.3.9, 37.7 U/mg of powder) from Worthington Biochemical (Lakewood, New Jersey); D-(+)-galactose, ascorbic acid, acetaminophen, uric acid, acetoacetic acid, bovine serum albumin (BSA), potassium ferricyanide $\left(\mathrm{K}_{3} \mathrm{Fe}(\mathrm{CN})_{6}\right)$, Triton $\mathrm{X}-100\left(\mathrm{C}_{14} \mathrm{H}_{22} \mathrm{O}\left(\mathrm{C}_{2} \mathrm{H}_{4} \mathrm{O}\right) n\right)$, and human serum (from human male AB plasma) from Sigma (St. Louis, MO); Carbon paste from Dupont (BQ922, Wilmington, DE); Silver paste from Asahi Chemical Research Laboratory (Tokyo, Japan); Insulator from Jujo Chemical (AC-3G, Tokyo, Japan); Flexible polyester films from 3M (St. Paul, Minnesota). Samples and standard solutions were prepared in a phosphate buffered saline (0.05 M PBS containing $140 \mathrm{mM}$ $\mathrm{NaCl}, \mathrm{pH}$ 7.5). In the case of serum measurements, same samples were dissolved in the same buffer containing $4.5 \%(\mathrm{w} / \mathrm{v}) \mathrm{BSA}$. All solutions were prepared with $18 \mathrm{M} \Omega / \mathrm{cm}$ de-ionized water (DIW) from a Milli-Q filter system (Millipore, Billerica, MA).

Apparatus. Amperometric experiments were performed with a $\mathrm{CH}$ Instrument Electrochemical Analyzer (600B, CH Instruments, Austin, TX). A semiauto screen-printer (LS-150, Neimitsu Kogyo, Tokyo, Japan) was used to produce strip-type disposable sensors. Photolam-320 (GMP, Korea) was used for lamination.

Fabrication of disposable screen-printed striptype sensors. Strip-type sensors were fabricated on polyester films (under and upper plates) (Scheme 1), and the three-electrode systems were composed of working (carbon), counter (carbon), and reference $(\mathrm{Ag} / \mathrm{AgCl})$ electrodes. First, the working electrode was printed on the polyethylene plate using carbon

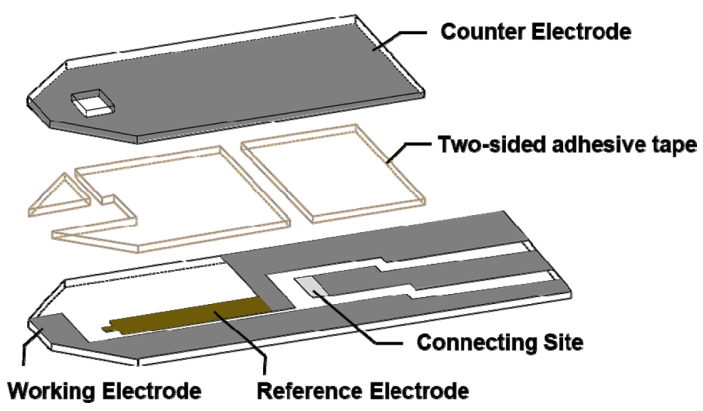

Scheme 1. Schematic illustration of a strip-type galactose sensor based on screen-printed carbon electrodes. 
paste and dried at $100^{\circ} \mathrm{C}$ for $10 \mathrm{~min}$, and the reference electrode was printed using silver paste and dried at $130^{\circ} \mathrm{C}$ for $5 \mathrm{~min}$. Next, the insulator was printed on the working electrode exposing a $2 \times 1 \mathrm{~mm}$ working area and dried at $100^{\circ} \mathrm{C}$ for $5 \mathrm{~min}$. High viscosity silver paste was then printed at the connecting site and dried at $130^{\circ} \mathrm{C}$ for $5 \mathrm{~min}$. The counter electrode was separately printed on another transparent polyethylene plate using carbon paste and dried at $100^{\circ} \mathrm{C}$ for $10 \mathrm{~min}$, and a connecting site was printed on the counter carbon electrode using silver paste and dried at $130^{\circ} \mathrm{C}$ for $5 \mathrm{~min}$.

Preparation of galactose sensors with co-immobilized enzyme and mediator. Prior to the experiment, a $\mathrm{Ag} / \mathrm{AgCl}$ reference electrode was treated with $0.3 \mathrm{M} \mathrm{FeCl}_{3}$ solution on a silver electrode for 10 min and rinsed with DIW. Next, enzyme and mediator mixture solutions of various compositions (0.05$0.2 \mathrm{U}$ GAO, $10-100 \mathrm{mM} \mathrm{K}_{3} \mathrm{Fe}(\mathrm{CN})_{6}$, and $0.2 \%(\mathrm{w} / \mathrm{v})$ Triton X-100 in $0.05 \mathrm{M}$ phosphate buffer $\mathrm{pH} 7.5$ ) were prepared. The mixture solutions were dispensed on the working electrodes $(2 \times 1 \mathrm{~mm})$ and dried for $15 \mathrm{~min}$ at $50^{\circ} \mathrm{C}$. The prepared electrodes were then covered with another polyethylene film (transparent upper plate) and affixed with double-sided tape. Finally, the strip-type electrodes were laminated at $25^{\circ} \mathrm{C}$ for rigidity.

Measurement of the sensor performance. An aliquot of $1 \mu \mathrm{L}$ of $400 \mu \mathrm{M}$ galactose solution was placed into the working electrode using capillary action. The various applied potential, buffer $\mathrm{pH}$, and the enzyme and mediator compositions for optimizing sensor performance were determined by cyclic voltammetry $(\mathrm{CV})$ and chronoamperometry. Calibration curves for galactose determination were obtained by plotting the currents versus galactose concentrations of $0-400 \mu \mathrm{M}$. Mixtures containing $400 \mu \mathrm{M}$ galactose and either $120 \mu \mathrm{M}$ ascorbic acid, $140 \mu \mathrm{M}$ acetaminophen, $60 \mu \mathrm{M}$ uric acid, or $30 \mu \mathrm{M}$ acetoacetic acid were prepared, and the corresponding interfering effects were estimated using the strip-type galactose sensors. Furthermore, recovery of galactose was determined from human plasma samples according to the reported methods [29-31]. The fresh frozen human plasma was thawed at $37^{\circ} \mathrm{C}$ and centrifuged at $3000 \mathrm{rpm}$ for $20 \mathrm{~min}$. The supernatant was separated into $1 \mathrm{~mL}$ aliquots and frozen at $-20^{\circ} \mathrm{C}$ until needed. Galactose standard in PBS ( $\mathrm{pH}$ 7.4) was used to spike plasma samples to the desired galactose concentrations and considered as samples of "unknown" concentration. All of the response currents of galactose were obtained by measuring the chronoamperometric response at $25 \mathrm{~s}$ under room temperature. The currents were generated through experiments repeated over 5 times, and the mean values and standard deviations are presented in Figures.

\section{Results and Discussion}

Operating principle of the electrochemical galactose biosensor. The operation of the proposed system is based on the interaction of galactose with the immobilized GAO. In this work, a well-known mediator, $\mathrm{K}_{3} \mathrm{Fe}(\mathrm{CN})_{6}$, was used as an electron transfer carrier.

As shown in Fig. 1, galactose first reacts with the GAO enzyme, and is oxidized to meso-galactohexodialdose. The enzyme is temporarily reduced by two electrons transferred from galactose. The reduced

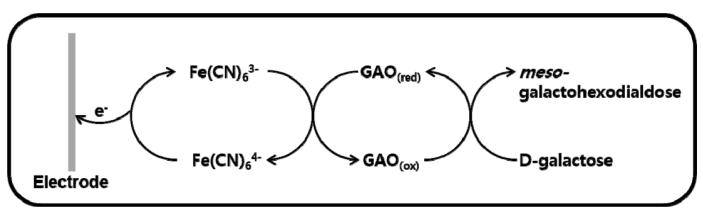

Fig. 1. Galactose response mechanism on the coimmobilized GAO and electron transfer mediator electrode system.

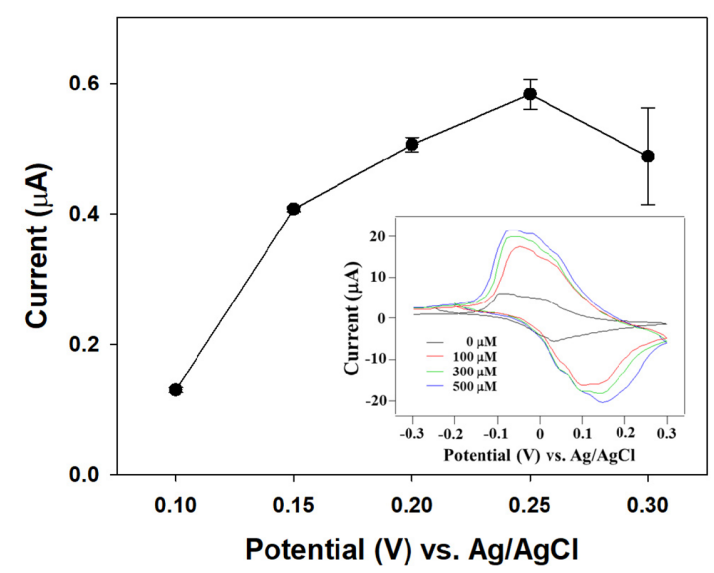

Fig. 2. Current responses for galactose $(400 \mu \mathrm{M})$ as a function of the applied potentials on the galactose sensor [GAO: $0.1 \mathrm{U} ; \mathrm{K}_{3} \mathrm{Fe}(\mathrm{CN})_{6}: 40 \mathrm{mM} ; 0.05 \mathrm{M}$ phosphate buffer $\mathrm{pH}$ 7.5]. Inset represents cyclic voltammograms to galactose $(0$ to $500 \mu \mathrm{M})$ at scan rate of $50 \mathrm{mV} / \mathrm{s}$. 
enzyme $\left(\mathrm{GAO}_{\text {red }}\right)$ next reacts with ferricyanide $\left(\mathrm{Fe}(\mathrm{CN})_{6}{ }^{3-}\right)$, transferring a single electron to each of two mediator ions. The enzyme is returned to its original state $\left(\mathrm{GAO}_{\text {ox }}\right)$ and the two ferricyanides $\left(\mathrm{Fe}(\mathrm{CN})_{6}{ }^{3-}\right)$ are reduced to ferrocyanide $\left(\mathrm{Fe}(\mathrm{CN})_{6}{ }^{4-}\right)$, transferring electrons to the electrode surface. The electrons are thus transferred between galactose and the electrode via enzyme and mediator. Thus, the final oxidation current is directly proportional to the galactose concentration in the sample.

Optimization of performance for galactose biosensors. Various reaction parameters (i.e., applied potentials, mediator concentration, $\mathrm{pH}$ value of buffer solution, and the amount of immobilized enzyme) were investigated to optimize the performance of disposable trip-type galactose sensors. In mediatorbased 'second-generation' biosensor, the maximum oxidation current of analyte is highly related to the redox reaction of the mediator [17]. Cyclic voltammetry was applied for the investigation of electrochemical properties of galactose sensor modified with $40 \mathrm{mM} \mathrm{K}_{3} \mathrm{Fe}(\mathrm{CN})_{6}$ mediator and $0.1 \mathrm{U} \mathrm{GAO}$ at $50 \mathrm{mV} / \mathrm{s}$ scan rate. As can be seen in Fig. 2 (inlet), the anodic and cathodic current peaks were observed at +0.12 and $-0.05 \mathrm{~V}$ (vs. $\mathrm{Ag} / \mathrm{AgCl}$ ) and proportional to the concentration of galactose. The experimental results showed reproducible anodic and cathodic peaks ascribed to a $\mathrm{Fe}(\mathrm{CN})_{6}{ }^{3-} / \mathrm{Fe}(\mathrm{CN})_{6}{ }^{4-}$ redox couple at the surface of electrode. To find the optimum operating potential for the galactose sensor, the oxidation current corresponding to $400 \mu \mathrm{M}$ galactose was measured between $0.1 \mathrm{~V}$ and $0.3 \mathrm{~V}$ applied potentials using same galactose sensor modified with $40 \mathrm{mM} \mathrm{K}_{3} \mathrm{Fe}(\mathrm{CN})_{6}$ mediator and $0.1 \mathrm{U}$ GAO (see Fig. 2). As the applied potential increased, the current gradually increased to $0.58 \pm 0.02 \mu \mathrm{A}$ up to $0.25 \mathrm{~V}$ but then slightly decreased at higher potential, indicating that the response of the enzyme electrode was controlled by the applied potentials leading to change the electrochemical redox of $\left[\mathrm{Fe}(\mathrm{CN})_{6}\right]^{-3 /-4}$. Thus, $0.25 \mathrm{~V}$ was chosen as the optimal applied potential in the subsequent measurements.

The optimal concentration of $\mathrm{K}_{3} \mathrm{Fe}(\mathrm{CN})_{6}$ mediator was determined by measuring the current changes at a constant enzyme ( $0.1 \mathrm{U}$ GAO) and galactose $(400 \mu \mathrm{M})$ levels in this sensor system. As shown in Fig. 3, the response current increased from $0.02 \pm$ $0.01 \mu \mathrm{A}$ to $1.01 \pm 0.04 \mu \mathrm{A}$ with concentration ranging from $10 \mathrm{mM}$ to $50 \mathrm{mM}$ but then decreased when

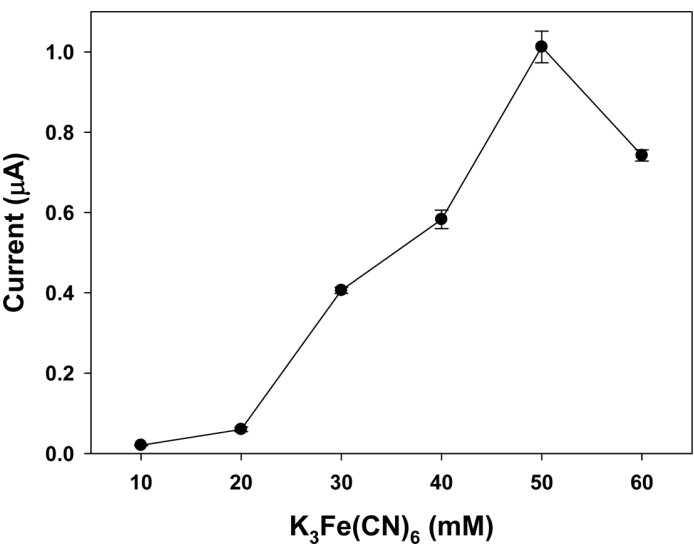

Fig. 3. Effect of $\mathrm{K}_{3} \mathrm{Fe}(\mathrm{CN})_{6}$ concentration on current responses over the galactose sensor [galactose: $400 \mu \mathrm{M}$; GAO: $0.1 \mathrm{U}$; applied potential: $0.25 \mathrm{~V}$; buffer $\mathrm{pH}$ : 7.5].

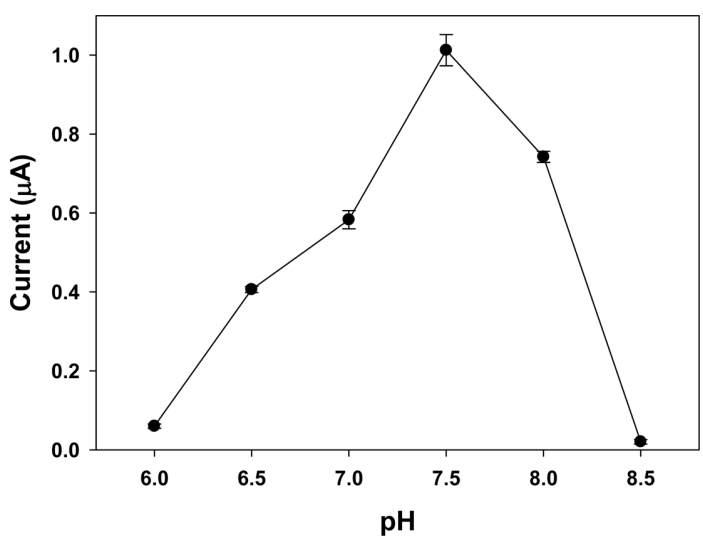

Fig. 4. Effect of operating $\mathrm{pH}$ on current responses over the galactose sensor [galactose: $400 \mu \mathrm{M}$; GAO: $0.1 \mathrm{U}$; $\mathrm{K}_{3} \mathrm{Fe}(\mathrm{CN})_{6}: 40 \mathrm{mM}$; applied potential: $0.25 \mathrm{~V}$ ].

the concentration of $\mathrm{K}_{3} \mathrm{Fe}(\mathrm{CN})_{6}$ increased to $60 \mathrm{mM}$, indicating that a higher amount of $\mathrm{K}_{3} \mathrm{Fe}(\mathrm{CN})_{6}$ may inhibit the enzymatic reaction under this condition. Also, the use of a higher concentration of mediator can lead to an increase in background current [25]. These results will be further discussed below and supported by galactose response being strongly dependent on the amount of mediator and enzyme (see Fig. 5).

The effect of buffer $\mathrm{pH}$ was explored in a $\mathrm{pH}$ range of 6.0 to 8.5 because the enzyme activity of the biosensor is affected by $\mathrm{pH}$. As shown in Fig. 4, at a $\mathrm{pH}$ of buffer solution of 7.5, the current reached a maxi- 
mum $(1.01 \pm 0.04 \mu \mathrm{A})$ and dramatically decreased with the $\mathrm{pH}$ increasing, which may be due to the inhibiting enzyme activity at higher $\mathrm{pH}$ under the reaction conditions. This result shows that the optimum $\mathrm{pH}$ in this sensor system is 7.5 , which is in accordance with optimum $\mathrm{pH}$ values reported by several groups for GAO immobilized on the electrode $[4,25,32,33]$. It has also similar to the $\mathrm{pH}$ of blood, making this sensor practical in real sample determination.

The activity of galactose response is highly influenced by the amount of enzyme immobilized on the electrode. Although $50 \mathrm{mM} \mathrm{K}_{3} \mathrm{Fe}(\mathrm{CN})_{6}$ was established as the optimal mediator concentration for $400 \mu \mathrm{M}$ galactose at the constant enzyme amount of $0.1 \mathrm{U}$ GAO, the optimal ratio of mediator/enzyme mixture on the galactose sensor was also determined. Fig. 5 shows the oxidation current as a function of increasing amount of GAO with a constant mediator/ enzyme ratio from $25 \mathrm{mM} / 0.05 \mathrm{U}$ to $100 \mathrm{mM} / 0.2 \mathrm{U}$. A high response current $(2.83 \pm 0.01 \mu \mathrm{A})$ was achieved with the $75 \mathrm{mM} / 0.15 \mathrm{U}$ ratio system. The increase in the amount of GAO on the electrode resulted in the increase of the sensor sensitivity as well as the increase of active sites on the electrode. It is important to note that the current decreased from GAO of $0.15 \mathrm{U}$ because higher amounts of mediator and enzyme are physically adsorbed on the electrode, which may restrict the diffusion of substrate to active site, and the oxidation current hence reduced [24,34].

On the above basis, the subsequent measurements

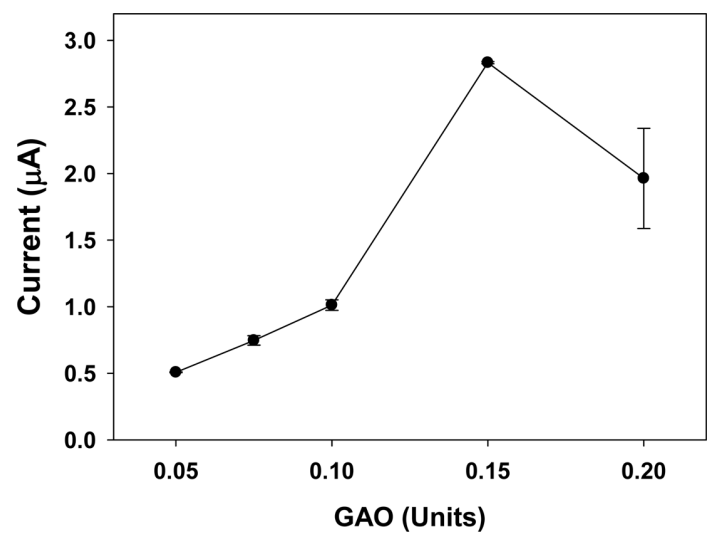

Fig. 5. Current responses with a constant mediator/enzyme ratio from $25 \mathrm{mM} / 0.05 \mathrm{U}$ to $100 \mathrm{mM} / 0.2 \mathrm{U}$ over the galactose sensor [galactose: $400 \mu \mathrm{M}$; applied potential: $0.25 \mathrm{~V}$; buffer $\mathrm{pH}:$ 7.5]. were carried out with a $75 \mathrm{mM} \mathrm{K}{ }_{3} \mathrm{Fe}(\mathrm{CN})_{6}$ mediator and $0.15 \mathrm{U}$ GAO using a solution consisting of $0.2 \%$ $(\mathrm{w} / \mathrm{v})$ Triton $\mathrm{X}-100$ in a $0.05 \mathrm{M}$ phosphate buffer of $\mathrm{pH} 7.5$ at a constant potential of $0.25 \mathrm{~V}$ under room temperature.

Calibration plot for the galactose biosensors. Galactose response was performed over the disposable strip-type biosensor modified with GAO and $\mathrm{K}_{3} \mathrm{Fe}(\mathrm{CN})_{6}$ mediator under optimized conditions. The required sample volume for the sensor to exhibit highly reproducible responses was less than $1 \mu \mathrm{L}$, which determined by the dimension and size of the strip-type sensor. Because galactosemia is induced when the galactose concentration in the blood of newborn is more than $240 \mu \mathrm{M}$, the sensitivity and reproducibility of the galactose biosensor were examined by using the $0-400 \mu \mathrm{M}$ galacactose sample [4,24]. Fig. 6 shows (A) the chronoamperometric
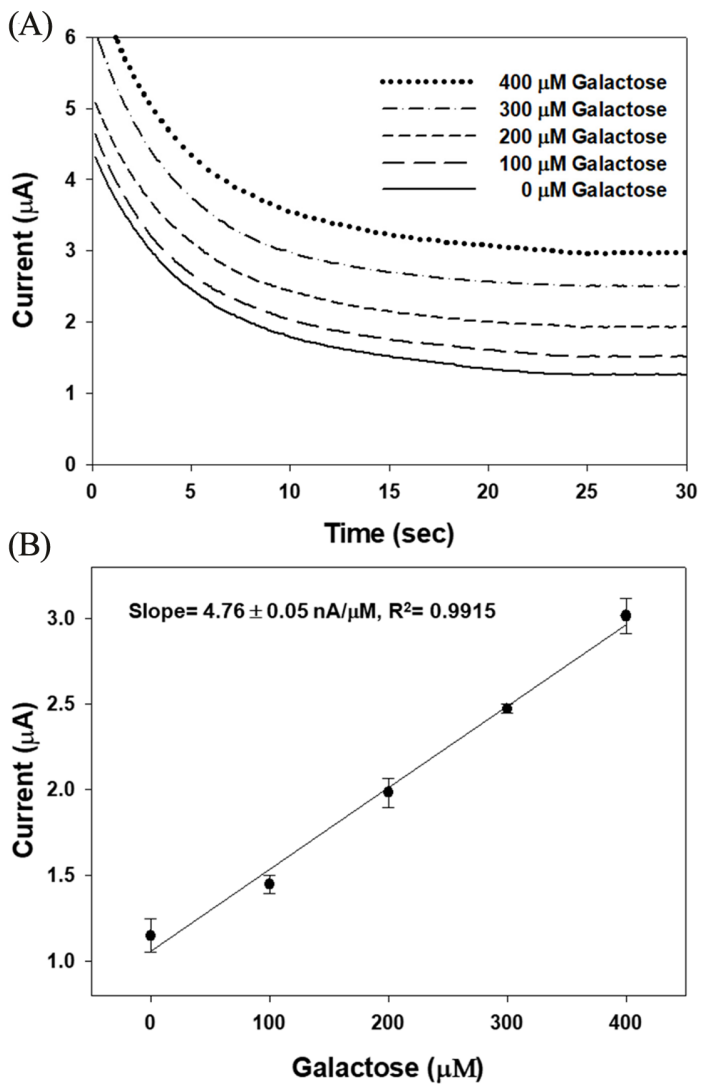

Fig. 6. (A) Amperometric response and (B) Calibration plot for the galactose sensor under the optimum conditions [galactose: $400 \mu \mathrm{M}$; GAO: $0.15 \mathrm{U} ; \mathrm{K}_{3} \mathrm{Fe}(\mathrm{CN})_{6}$ : $75 \mathrm{mM}$; applied potential: $0.25 \mathrm{~V}$; buffer $\mathrm{pH}$ : 7.5]. 
responses and (B) the calibration plot obtained with a constant potential of $0.25 \mathrm{~V}$ at $25 \mathrm{~s}\left(t_{95 \%}=<17 \mathrm{~s}\right)$. The amperometric response of the optimized biosensor to varying concentration of galactose was linear up to $400 \mu \mathrm{M}$ with a slop of $4.76 \pm 0.05 \mathrm{nA} / \mu \mathrm{M}$ and a correlation coefficient of $\mathrm{R}^{2}=0.9915$. In the calibration plot, each point was mean value generated through measurements repeated over 5 times. The standard deviation of each point was within $\pm 0.02 \mu \mathrm{A}$, which means the sensor-to-sensor reproducibility is more favorable on this optimized sensor system.

Amperometric biosensor for the measurement of galactose has been studied over immobilized GAO electrodes using planar-type SPCEs. For example, Kanyong et al. reported the sensitivity to galactose $\left(7.00 \mu \mathrm{A} / \mathrm{mM} / \mathrm{cm}^{2}\right)$ over galactose oxidase-cellulose acetate-cobalt phthalocyanine modified screenprinted carbon electrodes (GAO-CA-CoPC-SPCEs) [5]. In our strip-type sensor system, the sensitivity to galactose was $237.8 \mu \mathrm{A} / \mathrm{mM} / \mathrm{cm}^{2}$, which is approximately 34 times higher than that obtained with the planar-type SPCEs. The applied potential of this strip-type system $(0.25 \mathrm{~V}$, vs. $\mathrm{Ag} / \mathrm{AgCl})$ was a lower than in comparison to the planar-type system $(0.5 \mathrm{~V}$, vs. $\mathrm{Ag} / \mathrm{AgCl}$ ), which implies that the developed striptype sensor was favorable for minimizing interference of the common metabolites. The disposable strip-type biosensor for galactose possesses several key advantages over the planar-type galactose sensor including the accurate determination with small sample volumes less than $1 \mu \mathrm{L}$.

Effect of various interferences on the galactose biosensor. The current arising from oxidation of the physiological metabolites containing ascorbic acid, acetaminophen, uric acid, acetoacetic acid causes a severe problem in electrochemical biosensors $[2,4,25]$. Therefore, it is necessary to reduce the effect of interferents to promote selectivity for galactose. In this study, the $\mathrm{K}_{3} \mathrm{Fe}(\mathrm{CN})_{6}$ as electron transfer mediator, which required relatively a lower oxidation potential than those of interferents, is added to enzyme layer for suppression of interferents oxidation.

To explore the effect of the interferents, the response current of the fabricated sensor to $400 \mu \mathrm{M}$ galactose with solutions consisting of individual substrates with the normal physiology concentration in human blood were also conducted under optimized

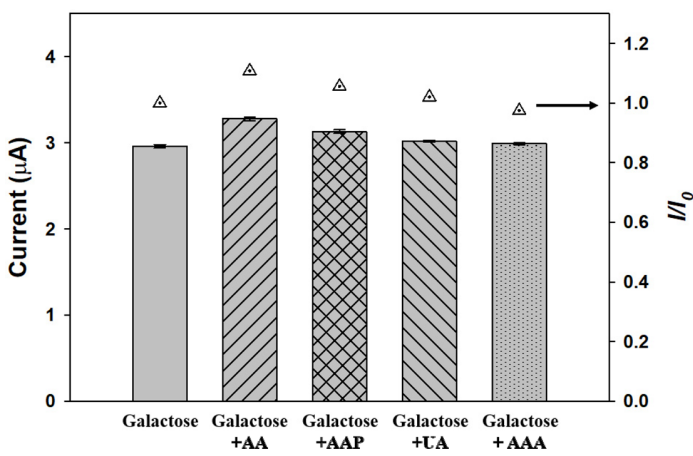

Fig. 7. Comparison of current profiles in the presence of interferents such as ascorbic acid (AA, $120 \mu \mathrm{M}$ ), acetaminophen (AAP, $140 \mu \mathrm{M}$ ), uric acid (UA, $60 \mu \mathrm{M}$ ), and acetoacetic acid (AAA, $30 \mu \mathrm{M})$ and each current $(I)$ plotted after normalization to the $400 \mu \mathrm{M}$ galactose $\left(I_{0}\right)$ [GAO: $0.15 \mathrm{U} ; \mathrm{K}_{3} \mathrm{Fe}(\mathrm{CN})_{6}: 75 \mathrm{mM}$; applied potential: 0.25 V; buffer $\mathrm{pH}: 7.5]$.

conditions. Fig. 7 shows that the response current of $400 \mu \mathrm{M}$ galactose was $2.96 \pm 0.02 \mu \mathrm{A}$. The presence of ascorbic acid, acetaminophen, uric acid, and acetoacetic acid in the sample produced response currents of $3.28 \pm 0.02 \mu \mathrm{A}, 3.13 \pm 0.02 \mu \mathrm{A}, 3.02 \pm 0.01 \mu \mathrm{A}$, and $2.99 \pm 0.01 \mu \mathrm{A}$, and corresponded to current after normalization to the galactose $\left(I / I_{0}\right)$ of $1.1,1.05,1.02$, and 1.01, respectively. These results reveal that this fabricated sensor with optimized operating condition was only slightly affected by ascorbic acid. Thus, this galactose sensor constructed by introducing a GAO layer with a $\mathrm{K}_{3} \mathrm{Fe}(\mathrm{CN})_{6}$ mediator is one of the best sensor system for amperometric determination of galactose to reduce the interferent effect by lowering applied potentials.

Determination of galactose in human plasma. To confirm the potential applications of the strip-type galactose sensor in practical analysis, unknown samples were analyzed using the strip-type galactose sensors. Table 1 shows the results obtained from unknown serum samples (initially containing

Table 1. Recovery studies using the optimized disposable galactose sensors

\begin{tabular}{ccc}
\hline \hline $\begin{array}{c}\text { Unknown } \\
\text { galactose } \\
\text { sample }(\mu \mathrm{M})\end{array}$ & $\begin{array}{c}\text { Determined } \\
\text { galactose } \\
\text { concentration }(\mu \mathrm{M})\end{array}$ & $\begin{array}{c}\text { Recovery } \\
(\%)\end{array}$ \\
\hline 200 & $193.8 \pm 9.5$ & $96.9 \pm 4.8$ \\
300 & $297.9 \pm 8.5$ & $99.3 \pm 2.8$ \\
\hline
\end{tabular}


$200 \mu \mathrm{M}$ and $300 \mu \mathrm{M}$ galactose). Recovery was calculated by comparing the response for galactose in serum. The applicable recovery from $96.9 \%$ to $99.3 \%$ and recovery standard deviation from $2.8 \%$ to $4.8 \%$ were obtained. These recovery values were favorably compared to recoveries mentioned by Manowitz et al. for their composite galactose biosensor (104.7 \pm $14.7 \%$ ) and Olsson et al. for their automated galactose analyzer containing immobilized GAO (101 \pm $4 \%$ ) [30,35]. Consequently, this developed strip-type galactose sensors were reliable to detect the galactose in human plasma.

\section{Conclusions}

In this work, the strip-type sensor electrodes assembled with $\mathrm{GAO}$ and $\mathrm{K}_{3} \mathrm{Fe}(\mathrm{CN})_{6}$ was developed and those of electrochemical properties were examined. The $\mathrm{K}_{3} \mathrm{Fe}(\mathrm{CN})_{6}$ mediator allowed a substantially lower applied potential $(0.25 \mathrm{~V}$ vs. $\mathrm{Ag} / \mathrm{AgCl})$ for galactose determination and minimized the effects of interfering substances. The strip-type electrode performed very quickly, with galactose content being established in less than $25 \mathrm{~s}$, and only required sample volumes of less than $1 \mu \mathrm{L}$. This disposable strip-type sensor was demonstrated to be sensitive, selective, rapid enough, and reproducible for the quantitative determination of galactose in the buffer and in human plasma samples, thus being ideal for use in POCT. These results may be applied to the design of a sensor system for the efficient determination of galactose in food science, fermentation industry, and medicine as well as for the clinical purpose. Future work will focus on the integration of various materials on the SPCEs to improve the electron transfer efficiency, thus enhancing the analytical performance of the sensors as well as approaching to measure the galactose level in the real blood and urine samples.

\section{Acknowledgement}

This study was supported by the National Research Foundation of Korea (NRF) funded by the Ministry of Science and ICT (NRF-2015M3A9E2029186) and the Korea Health Technology R\&D Project through the Korea Health Industry Development Institute (KHIDI), funded by the Ministry of Health \& Welfare, Republic of Korea (HI18C1039).

\section{References}

[1] F. Charmantray, N. Touisni, L. Hecquet, C. Mousty, Electroanalysis, 2013, 25(3), 630-635.

[2] S. I. Brahim, D. Maharajh, D. Narinesingh, A. G.-Elie, Anal. Lett., 2002, 35(5), 797-812.

[3] K. S. Park, S. S. Cho, D. Quan, J. S. Lee, G. S. Cha, H. Nam, Anal. Sci. Technol., 2007, 20(5), 393-399.

[4] K. Khun, Z. H. Ibupoto, O. Nur, M. Willander, J. Sens, 2012, 2012, 1-7.

[5] P. Kanyong, R. M. Pemberton, S. K. Jackson, J. P. Hart, Anal. Biochem., 2013, 435(2), 114-119.

[6] S. K. Sharma, R. Singhal, B. D. Malhotra, N. Sehgal, A. Kumar, Electrochim. Acta., 2004, 49(15), 2479-2485.

[7] S. K. Sharma, S. K. Singh, N. Sehgal, A. Kumar, Food Chem., 2004, 88(2), 299-303.

[8] J. Li, Z. Bai, Y. Mao, Q. Sun, X. Ning, J. Zheng, Electroanalysis, 2017, 29(10), 2307-2315.

[9] J. M. Henderson, F. W. Fales, Clin. Chem., 1980, 26(2), 282-285.

[10] G. A. Mason, G. K. Summer, H. H. Dutton, R. C. Schwaner, Clin. Chem., 1977, 23(6), 971-974.

[11] M. Fortelius, P. Mattjus, Chem. Phys. Lipids, 2006, 142, 103-110.

[12] A. Fujimoto, Y. Okano, T. Miyagi, G. Isshiki, T. Oura, Clini. Chem., 2000, 46(6), 806-810.

[13] C. J. M. Stroop, C. A. Bush, R. L. Marple, W. R. LaCourse, Anal. Biochem., 2002, 303(2), 176-185.

[14] P. Schadewaldt, H.-W. Hammen, K. Loganathan, A. Bodner, U. Wendel, Clin. Che., 2000, 46(5), 612-619.

[15] H. Gülce, İ. Ataman, A. Gülce, A. Yıldız, Enzyme Microb. Technol., 2002, 30(1), 41-44.

[16] J. Arora, S. Nandwani, M. Bhambi, C. S. Pundir, Anal. Chim. Acta., 2009, 647(2), 195-201.

[17] A. Chaubey, B. D. Malhotra, Biosens. Bioelectron., 2002, 17(6-7), 441-456.

[18] S. Ferri, K. Kojima, K. Sode, J. Diabetes Sci. Technol., 2011, 5, 1068-1076.

[19] E. Ekinci, A. Pasahan, Eur. Polym. J., 2004, 40(8), 1605-1608.

[20] G. Cui, S. J. Kim, S. H. Choi, H. Nam, G. S. Cha, Anal. Chem., 2000, 72(8), 1925-1929.

[21] M. A. T. Gilmartin, J. P. Hart, Analyst, 1995, 120(4), 1029-1045.

[22] A. E. G. Cass, G. Davis, G. D. Francis, H. A. O. Hill, W. J. Aston, I. J. Higgins, E.V. Plotkin, L.D.L. Scott, A.P.F. Turner, Anal. Chem., 1984, 56(4), 667-671.

[23] J. H. T. Luong, C. Masson, R. S. Brown, K. B. Male, A. L. Nguyen, Biosens. Bioelectron., 1994, 9(8), 577-584.

[24] J. P. Hart, S. A. Wring, Trends Anal. Chem., 1997, 16(2), 89-103.

[25] G. Cui, J. H. Yoo, B. W. Woo, S. S. Kim, G. S. Cha, H. Nam, Talanta, 2001, 54(6), 1105-1111.

[26] B. Dalkıran, P. E. Erden, E. Kılıc, Anal. Bioanal. Chem., 2016, 408(16), 4329-4339.

[27] P. Kanyong, G. Hughes, R. M. Pemberton, S. K. 
Jackson, J. P. Hart, Anal. Lett., 2016, 49(2), 236-244.

[28] J. D. Newman, A. P. F. Turner, Biosens. Bioelectron., 2005, 20(12), 2435-2453.

[29] P. J. Taylor, E. Kmetec, J. M. Johnson, Anal. Chem. 1977, 49(6), 789-794.

[30] P. Manowitz, P. W. Stoecker, A. M. Yacyntch, Biosens. Bioelectron., 1995, 10(3-4), 359-370.

[31] G. Cui, J. H. Yoo, J. Yoo, S. W. Lee, H. Nam, G. S. Cha, Electroanalysis, 2001, 13(3), 224-228.
[32] T. Yao, K. Takashima, Biosens. Bioelectron, 1998, 13(1), 67-73.

[33] F. A. Vega, C. G. Núñez, B. Weigel, B. Hitzmann, J. C. D. Ricci, Anal. Chim. Acta., 1998, 373(1), 57-62.

[34] J. Njagi, S. Andreescu, Biosens. Bioelectron, 2007, 23(2), 168-175.

[35] B. Olsson, H. Lundback, G. Johansson, Anal. Chim. Acta., 1985, 167, 123-136. 